\title{
Auctioning Patronage in Northeast Brazil: The Political Value of Money in a Ritual Market
}

Aaron Ansell

\begin{abstract}
Fundraising auctions help people in a small rural town in Northeast Brazil reckon with the effects that currency stabilization and democratization have had on municipal politics. These simultaneous processes have made politics confusing for the people of Passerinho by creating multiple modalities of electoral reciprocity. In this article, I argue that the ritual procedures of the auctions commensurate these modalities of reciprocity through a semiotic procedure in which money signifies both exchange value and more personal forms of value. I consider the auction's impact on municipal politics by looking at its effect on the narrative of democratic progress and on the prestige of grassroots politicians, traditional elites, and voluntary associations.
\end{abstract}

Keywords: auction, Northeast Brazil, money, value, democracy

\section{THE POSSIBILITIES OF MONEY AND AUCTIONS IN A SMALL BRAZILIAN TOWN}

In the town of Passerinho, deep in the semiarid backlands (sertão) of Northeast Brazil, national social and economic policies have disrupted the value system that girds local patronclient exchange. Currency stabilization and social-assistance policies increasingly monetize electoral transactions, threatening moral, long-term clientelist reciprocities. Yet, even as the vote is commodified, democratic social movements stigmatize nepotism and clientelismo. In this context, Passerinhos use village fundraising auctions to reestablish the moral coherence of municipal politics. Auction bidding produces new, reassuring forms of value. In exploring these processes, I build on the work of others who have argued that money can commensurate qualitative differences without relying on exchange value as the sole basis of commensurability.

The idea that people can use money to signify extraeconomic cultural values has partly emerged from a critical appropriation of Georg Simmel's sociology (see Appadurai 1986). Simmel embeds money in a modern, cosmopolitan universe in which it expresses the anonymous relations among subjects. This is because money "is incapable of expressing the individual element" of any exchange object or person (Simmel 1964:390-391). On the one hand, ethnographic work has borne out Simmel's thesis, showing how societies protect their categorical distinctions from the flattening effects of money by separating spheres of exchange (Bohannon and Bohannon 1968). As modern money spreads globally, societies engage in a variety of such defensive tactics, including the enclaving of certain exchange objects, the laundering of money into community-enhancing wealth, and the creation of "special purpose currencies" (see Maurer 2006). On the other hand, many recent scholars posit that money can reaffirm local hierarchies and classifications (Guyer 2004). People can deploy money's “uniscalar valuation template" (Kelly 1992:102) to signify personal talents (Barber 1995), modernist subjectivities (LiPuma 2000), and ethnic solidarities (Cattelino 2009).

Like money, markets can convey noneconomic values rather than efface them. Spiritual practices and political relations mediate markets on the capitalist periphery (Comaroff and Comaroff 1999; Geschiere 1997; Gould and von Oppen 1994:6-7; Hewitt de Alcántara 1992:7), as well as at the high centers of digital finance (Garsten and Hasselström 2003; S. Green 2000). In short, capitalism's most fundamental forms are vulnerable to us. We can saturate them with our anxieties, fetishes, and fictions and structure them with our political practice (see Maurer 2006:18-19).

This vulnerability comforts those of us who want to regain a sense of local control over macroeconomic processes, but it may not comfort people who associate local circumstances with social disorder. In such cases, the seemingly external aspects of capitalist money and markets may offer reassurance by appearing to stand above the fray of factional conflicts or systemic discordance. I argue that in Passerinho's confusing political moment, its inhabitants implicitly look to 
money's exchange value to help them sort out politics. Their ritual appropriation of exchange value enables them to posit and calculate new, more personal value forms. Paradoxically, new value forms add a sense of continuity and viability to political life.

This is not to claim that people hold auctions with the intent of clarifying chaotic systems. They often hold them just to make money or to buy things cheaply. Auctions are good for making money within contexts in which normal systems for calibrating value have broken down: when antique experts disagree, when the stock market crashes, and when those divorcing want to hurt one another (Smith 1990). The auction resettles the valuation system - or, at least, creates a spatiotemporal pocket of value coherence through a ritual procedure. Variations in this ritual procedure allow sturdy social values to stabilize capricious markets and stable markets to secure chaotic social arrangements. I would thus define an auction as a ritually regulated market in which what is "regulated" is the relationship between the exchange value and the cultural values that codetermine the status of the items sold.

Critical theories of auctions have tended to privilege the cultural forces underlying the valuation of auction prizes. For Jean Baudrillard (1981:117), the exchange value of the money bid at the European art auction is "transmuted" (transduced) into a "sign value" - namely, that of "aristocratic parity” among wealthy bidders. Oren Kosansky's study (2002) of sacred charity auctions in Morocco shows how wealthy tourists transduce the capital they bid into quantities of spiritual devotion, which the saints then convert to "divine recompense" to ensure the bidders' prosperity. In the process, Moroccan charity auctions reproduce hierarchies of wealth among Jewish pilgrims by framing them as hierarchies of piety (Kosansky 2002:389). Kosansky's insight into the cosmological legitimation of wealth-based hierarchy helps me to understand the political repercussions of Passerinho's auctions as well as the nature of fundraising (or charity) auctions in general. But I differ with him and Baudrillard in my assessment of the status of exchange value in the auction. Both their analyses imply that the auction effects a certain hiatus of the prize's commodity status. It is this hiatus that makes room for the cultural values that the bidding embeds within the prize. But in Passerinho, I do not think this is the case.

I argue that Passerinho's auctions neither suspend commodity value nor transduce it into more personal value forms. Rather, the money bid indexes multiple value forms at the same time. Money's polyvalent quality in Passerinho is no mere happenstance. The capacity of the auction to delineate cultural value forms actually depends on the money's simultaneous signification of the prize's commodity value. The bidders' knowledge of the prize's price on outside markets allows them to calculate the added cultural value they invest in the prize through their bidding. The quantifiability of cultural value forms lends them an aura of validity, even though these value forms may have shallow historical roots.
It is precisely this fake ontological grounding that has become such an anathema to grassroots political movements in Passerinho. Therefore, in this article, I meditate on the fundraising auction as a sphere of ersatz political deliberation in the municipality. The following section explores the contemporary disarray of Passerinho's system of political reciprocity in light of the dual processes of monetization and democratization. After situating the fundraising auction in an emergent grassroots organization, I argue that auction bidding generates two value forms (força and união) that commensurate distinct modes of gaining political prestige and establishing group solidarities, respectively. I use an ethnographic vignette to show how these new value forms legitimate old hierarchies. I then look at the way Passerinhos critically engage the auction's semiotic machinery and reflect on the ritual's overall implications for democratic change.

\section{THE SIMULTANEOUS MONETIZATION AND DEMOCRATIZATION OF CLIENTELISM IN PASSERINHO}

Patron-client relations in the sertão have been shifting since colonization, but recent federal policy has changed these relations so quickly and drastically that now Passerinhos themselves feel confused about how to "do politics." Longterm clientelist exchanges, which predominated throughout the 20th century, now hang by a thread as monetization and democratization undermine their morality and economic viability. Consistent with Jonathan Parry and Maurice Bloch's thesis (1989) on the moral valence of "transaction orders," Passerinhos generally consider short-term (cash) clientelism amoral in comparison with long-term (material) exchange and view the latter as less moral than democratic exchanges that ultimately lead to good policies and community abundance. Practical and ethical choices in a world that combines all three kinds of political exchange, however, sow confusion.

In the now-declining political order, rich men (mainly ranchers) gained the political support (votes, attendance at events, and campaign labor) of poor families through gifts that sustained agricultural and human life cycles. The gifts were given seasonally, corresponding to the cultivator's need for certain farm inputs - wire, seed, pesticides, and so forth - which supported a household's corn, crops, and small-animal pastures for a few harvests. Municipal politicians also transported the ill elderly and parturient women to hospitals owned by allied state politicians. Local patrons tended to dispense more of these gifts during the "political season" - that is, the period just before and during the official campaign season when the municipality bifurcates into two warring party coalitions (Palmeira 1996). They were also obliged to act as "men of good heart" whenever family or farm emergencies arose (Chaves 2003).

Poor farmers boasted of their ties to such men of força (strength) and proudly worked to extend these men's prestige. The term força, still in use in Passerinho, evokes a moral, paternal strength insofar as it expresses a man's capacity to 
project his good name across kin groups and throughout generations (Munn 1992). A self-respecting farmer promotes these long-term connections not only by voting for his patron in sequential elections but also by controlling the votes of his coresident dependents-his children, wife, siblings, and siblings-in-law (Heredia 1996). One man in his sixties told me that up until two decades ago even married men who lived in their own households often "respected our fathers by following him in the vote" (conversations with author, June 11, 2009). This patriarchal "unity" (união) of the extended family was surely more an ideal than a reality, but it was an ideal that oriented real practices meant to sustain a family's reputation.

Grounded in the patriarchal authority of both the patron and the client, these patrilineal loyalties (in an otherwise bilateral kinship system) indirectly linked cultivators to state and federal politicians. Municipal patrons told their clients that "to work for the people" they needed resources from higher-up state and federal deputies whose favor they could only win by delivering the cultivators' votes. Thus, common people voted for the legislators and executives of their patron's choosing, both to sustain these resource flows and to express respect. One man who still idealizes this norm explained to me that, "just as we vote for the mayor our fathers like, we vote for the senator our mayor likes" (conversation with author, June 11, 2009). Scholars studying Brazilian clientelism generally believe that this system of political integration shores up the power of conservative state oligarchs throughout the sertão and the Northeast in general (Leal 1977; Woodard 2005).

\section{Monetization}

The recent monetization of Passerinho's economy has partly replaced the long-term moral exchanges with commodified vote buying. Here, monetization should be understood as a relative term. To some extent, cash has circulated in Passerinho since its colonization by cattle ranchers in the 17 th century (Mott 1985), but it has rarely come to the smallholders who have barely enough beans and corn to sustain themselves. Like many in the sertão, Passerinhos used reciprocal labor rather than hired hands in their fields, bartered small livestock with one another, and occasionally sold animals to regional traders. Moreover, people generally stored capital as livestock, not cash. Like the urban middle class Maureen O’Dougherty (1999) describes, Passerinhos had little trust in cash, especially during the 1980s when Brazil's currency became hyperinflationary (Amman and Baer 2000; J. Green 2000). Thus, cash played a negligible role in electoral politics until the 1990s, when the municipality underwent rapid monetization.

In 1994, Fernando Henrique Cardoso created a fiscal plan pegging Brazilian currency to the U.S. dollar, ending hyperinflation (Amman and Baer 2000). Other structural adjustment measures (e.g., the opening of trade barriers to multinational agribusiness) led to falling bean and corn prices that hurt small cultivators throughout Brazil, including those in Passerinho who had saleable surplus (Farina 2002; Helfand 2003:17-19). Buying food, however, became easier. Supermarkets with cheap commodified foods cropped up in Passerinho, obliterating several local cottage industries (mainly manioc flour and sugar candy).

Many Latin American leaders adopted similar measures around the same time, much to the dismay of left-wing political actors like those in Brazil who labeled Carodoso a neoliberal. But Cardoso also sought remedies for the problems generated by structural adjustments, he-as well as later President Lula-experimented with "second-generation" neoliberal policies. These were antipoverty measures created to mollify the hardship inflicted by the withdrawal of subsidies and other forms of state assistance (Craig and Porter 2006; Pastor and Wise 1999). Time-limited cash grants targeting the poorest of the poor cushioned the blow for many rural families (Hall 2006; Soares et al. 2006). In Passerinho, these grants have expanded local consumption of basic food commodities.

In addition to these targeted cash grants, Passerinhos gained another source of cash. Monthly rural pensions, which the rural labor movement fought to codify in the Constitution of 1988, finally became a reality for Brazil's rural workers in 1991 (Veras 2001). Thus, cash, while always a feature of municipal life, expanded during the 1990s. Moreover, the acquisition of cash grew more regular during this time. While partisanship continued to mediate access to these policy sources, families became less dependent on the goodwill of patrons with whom they engaged in informal exchange. Regular sources of cash created a consumer appetite that federal programs and pensions could not satiate.

By the mid-1990s, Passerinhos were stashing bills under their mattresses. They started saving for newly available durable goods-motorcycles, televisions, sound systems, and DVD players - that fed into modernist narratives of progress figured in terms of individuated tastes and personal mobility. Many families began paying for farm labor rather than "trading days" with kin and neighbors. Finally, the barter of local livestock for family consumption shifted to an informal cash market, in which the price of a sheep or chicken was relatively stable. Today, Passerinhos say their prices are informally fixed to those of their counterparts in the stores, costing between 10 and 20 percent less than the latter.

Passerinhos do not worry about the overall monetization of their economy - in general, they see it as a sign of progress - but many worry about the monetization of political exchange. Since I began my research in Passerinho in 2003, a variety of people have reported a consistent increase in cash buy offs on the eve of municipal elections - and, to a lesser extent, state and federal elections. It was hard for me to ascertain the precise scope of this practice in interviews. People initially feared I would bust them for violating federal election laws because I was rumored to be an employee of the federal government and because of my initial interest in 
the national antipoverty policy. Still, other anthropologists have confirmed the increase in cash clientelism in the sertão (Barreira 2006; Villela 2004).

Although vote buying carries a stigma among both commoners and politicians, its popularity is increasing. As one older woman joked, "The people who take money from politicians used to be the drunkards. But now, we are all drunkards" (conversation with author, June 20, 2009). Indeed, young couples just starting out, landless people, and single mothers - very cash-needy groups - guiltily admit to trading votes for cash. Rich politicians have mixed feelings about this. The mayor told me that it "doesn't build a man's respect," but a town councilman said that cash exchanges leave "a politician free" after the election. Most politicians agree that when they deal in cash, they are less capable of delivering votes to their own patrons at state and federal levels. Cash clientelism does not offer any ongoing stream of goods and services to the client such that he would care about the patron's own line of higher-level support, and it builds no moral credit for the patron such that the client would believe that he is helping a good man "work for the people” by voting for his state-level benefactor.

The problem for both politicians and commoners is that they do not know how they should value these two forms of political currency in relation to the vote. Are both necessary to secure votes, or will either suffice on its own? How much cash does a politician need to give someone to make that one-time gift obviate the need for ongoing gifts of farm inputs? This is a matter of ethical as well as economic value because the question can be reframed as follows: How much money is it worth to overlook the abandonment of virtuous reciprocities? In the 2004 municipal elections, several people told me that 50 reais (about \$20) was the going rate for a vote (for mayor). Yet as I asked around, I found that some individuals received more if the candidate thought they could rustle up votes from others. Moreover, some people received farm inputs in addition to the standard 50 reais. I tried to ascertain whether these farm inputs were negotiated out of ethical or economic concerns, but I had to leave Passerinho suddenly in October after being accused of being a campaign strategist for the opposition. ${ }^{1}$

Linked with this value confusion is a shift from the household to the individual as the client unit of the electoral exchange. Yet there is much confusion here as well. Politicians and commoners experience uncertainty as to whether a given long-term exchange encompasses all the household's members or just its head. Patrons can never be sure which individuals are really operating as independent client units. Despite this confusion, young people and women acknowledge their increased political worth in recent years. Never before have politicians solicited their votes independently from their fathers and husbands. This call to arms of women and youth resonates with new democratic discourses that demand an end to both paternalist gifts and cash buy offs. But clientelism can operate at the individual level just as easily as liberal democracy. In fact, patrons use the language of in- dividual freedom and empowerment (of youth and women) when courting new votes, and they look to individuating mechanisms of monitoring voters' allegiances. (Witness the increasing use of campaign stickers on the sides of motorcycles, a perfect instance of individual upward accountability to political patrons.)

\section{Democratization}

The same neoliberal period that saw the monetization of so many clientelist relations also coincided with Brazil's redemocratization (1985-present). During this period, Brazil experienced an increasingly "insurgent citizenship," a broad front of combative unions, urban squatters, and other new social movements that spoke out against the violence and clientelism endemic within Brazilian politics (Holston 2008). In Passerinho, anticlientelist discourses that had been brewing for decades came to a boil, and political exchange became even trickier to navigate.

Liberal priests from Germany and Italy entered Passerinho in the 1960s (during Brazil's military dictatorship) and organized Base Christian Communities (Comunidades Eclesiásticas de Base, or CEBs) in its villages. These CEBs advocated for both an end to the military dictatorship (1964-85) and a general spread of social activism among the poor. Their rhetoric emphasized the need for horizontal "unity" (união) among cultivators rather than vertical união among family members subordinated to a patriarch. Organized into “communities," villagers would, ideally, lift themselves out of poverty rather than relying on the generosity of local politicians.

While Passerinho's CEBs, like many others in the region, faded during the 1980s, a number of new social movements has emerged in their wake (Adriance 1994). The CEB chapels now headquarter community-development associations. These are among the most dynamic rural institutions in Northeast Brazil and have become the paradigmatic symbol of rural democratization in the backlands (Costa et al. 1997). Villagers join these chartered institutions to capture community-development projects from the World Bank and other NGOs. The presidents of these associations meet in a municipal council every month to design proposals for new projects and to allocate existing projects among the villages.

Alongside these associations, Passerinho saw a blossoming of an Afro-Brazilian movement, a women's movement, and a broad coalition of progressive development agronomists during the 1990s. Activists from these movements are now running for local office. They do not have the money to buy votes or farm inputs, but their local leader, Maria, claimed that she and others "gave the people consciousness, organization, and ... good policies" (conversation with author, January 10, 2005). This form of democratic exchange has a longer temporal horizon than traditional clientelism insofar as it leans on an eschatological timeline in which democracy will bring about an end to all injustice. These democratic exchanges have made social mobilization an alternative way of accruing not only votes 
but also moral political prestige. As one might imagine, Passerinhos are still working through the ethical and practical questions that come with combining and substituting democratically motivated votes for material exchanges.

In sum, Passerinhos have to balance the simultaneity of three modes of political exchange, each of which has different normative implications. This simultaneity results from a complex set of policies crafted in the maw of deregulation and state rollbacks. Like the urban residents of Salvador described by John Collins (2008), Passerinhos often deal with the dislocations of this period by wrapping themselves in patron-client networks that they can better navigate. These hierarchical networks furnish the critical standpoint through which rural Brazilians distance themselves from individualism and egalitarian democratic ideals (Dent 2007). Passerinhos speak about phasing out the modes of political exchange that they have come to see as retrograde, even as they curl up under the wing of power (see Whitehead 2002:180). Their discourses sometimes link family-based clientelism to the past, cash buy offs to the present, and democratic mobilization to the future. "We are just cash crazy right now," said one agronomist. "Soon this will pass and our people will gain more consciousness" (conversation with author, April $5,2004)$. It is this narrative of democratic progress that offers them some assurance that the chaotic simultaneity of these exchange modalities is transient.

The auction jeopardizes this narrative.

\section{THE COMMUNITY FUNDRAISING AUCTION}

At first glance, village fundraising auctions seem to substantiate talk of democratic progress by contributing to the financial autonomy of community associations. The help is much needed; the associations are fragile. They face financial challenges: taxes, chapel maintenance, and structural improvements. Moreover, as months and years go by and each association remains in waiting for a World Bank development project, its members lose heart. "We try to keep the community's união strong” (conversation with author, June 17, 2004), their presidents often assured me, but membership and attendance continue to dwindle. Fortunately, as one man told me, "we have the auction to sustain us" (conversation with author, June 17, 2004).

Hundreds of people from throughout Passerinho will attend an association's yearly auction "to help the people of community X" (conversation with author, June 5, 2009). ${ }^{2}$ They gather in a horseshoe-shaped crowd in front of the chapel, where an auctioneer stands on a box with a table and microphone in front of him and the prize held high in his hand. The auctioneer is a local farmer himself, known for his boisterousness and good humor. He is the only auction official, and he "yells the bids" free of charge (unless one counts booze and dinner). Objectively, the gathering appears to be an undifferentiated mass of individuals standing shoulder to shoulder, but Passerinhos recognize the distribution of groups and status differences throughout the space. Dozens of bidders stand directly in front of the auctioneer. They are both commoners and politicians. Politicians bid individually, but their entourages stand around them. Commoners bid in groups (with pooled money), but their companions stand off to the sidelines. Filling the space between are unaffiliated individuals: children, teens, widows, and derelicts. These people do not bid, but they do come to the center of the gathering when politicians share winnings with "the people."

Each of Passerinho's 25 associations plans its auction two to three months in advance. The men travel to the nearby city, where they pay for radio announcements and make arrangements for the generator and sound system. Women and youth solicit town families and politicians to donate prizes. The former usually give a cake or a roasted chicken; the latter give combinations of roasted pork ribs, sides of beef, and bottles of booze. The market value of these items usually falls between ten and 100 reais, but the winning bids always exceed these values. Politicians, who typically bid only against other politicians, may pay up to five times the prize's market price. Commoners, who bid in groups, usually pay about twice the (informal) market price. All in all, the host association knows that it is benefiting from "the goodness of the people" (conversation with author, July 28, 2009). Indeed, fifty prizes (average for an evening) can yield a profit of up to 3,000 reais, more than enough to bankroll the association for another year, pay for a new floor, and revitalize its members' flagging enthusiasm.

\section{THE AUCTION'S MEDIATION OF POLITICAL RELATIONS}

Economists generally believe that people hold auctions when market conditions are uncertain (e.g., when currencies are unstable, when supply is unpredictable, when the antique experts disagree, etc.). The auction creates a pocket of economic stability by operating as a miniature market - but a more perfect market insofar as its real-time, face-to-face immediacy optimizes the match between individual supply and demand (Cassady 1967; Holt 1980; Myerson 1981; Riley and Samuelson 1981; Zheng 2002). Anthropologist Charles Smith (1990:3), in his seminal book on auctions, critiques this neoclassical approach by suggesting that auctions are rituals in which the cultural values of the auction public redefine and resolve ambiguities of economic value. He goes on to explain that the "true power of the auction is that its attribution of value represents the collective judgment of the entire community" (Smith 1990:77). Both Smith and the economists are really thinking only of the paradigmatic commodity auctions in which the whole point of the ritual is to affect the general market or at least to create avenues of profitable activity in uncertain market contexts.

Commodity auctions of this sort could once be found in Passerinho. Individual cultivators, usually male family heads, used to hold "private auctions" on their farms. Unlike today's fundraising auctions, the prizes consisted of livestock from the individual's own holdings; they were not solicited as donations. The owner kept the profit but claimed that he held the auction "to repay a promise" to a saint. When I 
asked if participation in these auctions was altruistic, people claimed that men really held them "because they thought the time was right to sell" and that the public bid on the prizes to acquire items on the cheap, not to "make another man rich" (conversation with author, June 5, 2009). These private auctions thus seem to have revolved around capital speculations conditioned by the region's fluctuating commodity prices. The stabilization of the national currency and the prices of local food commodities perhaps contributed to their decline.

Conversely, market stabilization has enabled the emergence of the community fundraising auction. The logic of the fundraising auction inverts Smith's understanding of auction value dynamics. In Passerinho, there is no longer any ambiguity with respect to the price of auction prizes on the local market. The ambiguity is instead found in the social relations among the bidders - namely, in the plurality of modes of gaining political prestige. The fundraising auction, in a kind of parody of the commodity auction, deploys the certainty of market values to resolve ambiguities in the social (read: political) world of the auction public. The exchange value of a prize on the informal livestock market - which Passerinhos know down to the penny - serves as a kind of value platform within the auction. As bidding lifts the object's price higher from this platform, the difference between the market price and the auction sale price reveals the amount of social value that the bidder has invested in the prize.

I argue that the terms força (strength) and união (unity), which today have multifaceted political meanings outside the auction, assume new life as value-forms within the fundraising auction. Politicians literally avow that their bidding "shows the people their força," and commoners (who bid in groups) toast "to our união" when they win a bid. Here I will focus mainly on the term força because of its more direct link to the question of political exchange. The problem I want to address is the following: Given that there are qualitatively different forms of political força that derive from different kinds of political exchange, what kind of força does auction money signify? Does the auction privilege one form of força over the others? If it does, Passerinhos might walk away from the event with a sense that, say, long-term reciprocities remain the proper mode of achieving power, or that all is for sale in the world, or that democratic, grassroots activism is the only legitimate politics. I suggest that the form of value into which money is transduced is really a combination of the three forms of exchange and that this blend effects a ritual suspension of the qualitative differences among political ethics and actors.

\section{The Commensuration of Disparate Types of Political Força}

One afternoon in early January of 2005, I accompanied Henrique, Passerinho's mayor and a wealthy rancher, to a community auction in a remote village. The villagers held the event several months before the political season began because they wanted to christen their new chapel before
I left for the capital city. (I had lived in the village for several months.) Also present at the event were several representatives of Piaui state's Movimento Quilombola, an Afro-Brazilian political movement that advocates for the cultural and economic rights of rural communities descended from escaped slaves (see French 2006). The auction was poorly attended. In the open air surrounding the chapel, only about 50 people stood in front of the auctioneer. Modulating his tone, volume, and cadence, the auctioneer struggled to lure people into bidding on the roasted chickens and liquor that comprised the prizes. He lowered the starting prices, but the villagers were slow to jump in, and they purchased only a few items at low prices.

Suddenly, Henrique started to bid. Buying chicken after chicken, bottle after bottle, he laid the prizes on a table that stood next to him, and dozens of villagers picked wings and thighs from it and filled plastic cups with booze and soda. The people from Movimento Quilombola, however, did not eat from the table. Instead, Maria, the movement's regional leader, said, "Of course he can win the prizes; he has the money of the mayorship to spend" (field notes, January 8 , 2005). Henrique replied, "Well, then you bid for the union and I'll bid for the mayorship" (field notes, January 8,2005 ) - referring to the fact that Maria also worked in the rural union. Maria protested, "My força comes from my organizing the people," but she eventually entered the match. The wealthy Henrique outbid her easily. Then, after collecting his prize, Henrique approached Maria and placed the sweet cream into her hands. At first she refused, but Henrique hugged her, saying that it was "all in good fun." Maria and her group then went to the sidelines and ate the container of sweet cream.

Henrique walked away very satisfied from the auction. Maria did not. By drawing her into a bidding contest, Henrique matched his own political persona against Maria's. The auction let him use his money to turn their qualitatively different political identities and ethics into quantifiable values of força. As a value form attached to auction bids, força assumed an abstract character, encompassing all three forms of political prestige. Here I draw on David Graeber's insight that the value of money lies in its identification with its holders' "hidden life force or agency behind it" (2001:105). The key to Graeber's theory of money's concealment-based value lies in the plurality of possible actions of which the subject is believed to be capable. This "sheer, formless potential... [constitutes a form of power the] generic nature [of which] is itself a way of representing ... unlimited possibility" (2001:110). If we assume that people imagine "unlimited possibility" through the local categories, then auction bids among politicians suggest that contestants could wield all three modes of power that derive from the different modes of political exchanges.

I think Henrique intuited the semiotic implications of the bidding and was thoroughly pleased by them. His auction victory both affirmed that he was a man who commoners "could put their faith in" (for long-term exchanges) and that 
he had democratic credentials. The latter was more problematic for Henrique. As a semiliterate rancher affiliated with the conservative Popular Party, he was rarely sought out by state government agents under the command of the Workers' Party governor. World Bank and FAO agents saw him as a dime-a-dozen hick, someone totally disconnected from their technically sophisticated, participatory development projects. Auction victories like this one relieved Henrique of the need to participate in project-planning sessions and social-movement events, and they made him more credible when he did.

The commensuration of the three modes of exchange upsets the narrative of democratic progress to which many Passerinhos subscribe. The interchangeability among the three exchange forms makes the current state of Passerinho's political affairs appear not as a rough stretch along the road to democracy but, rather, as a continuation of an enduring social order for which tacit rules of engagement are already known. Democratic prestige is repackaged, like old wine in new bottles. Commensuration replaces its teleology with an "analogic" temporality in which social changes are "ongoing variations in a continuous whole" (Goodwin 2002:29).

\section{Hierarchization and the Fundraising Auction}

Henrique's goal in cajoling Maria into the contest was not just to earn democratic credentials but to establish his superiority to her in moral, rather than purely economic, terms. Indeed, the bidding semiotically erased the obvious fact that Henrique's greater wealth enabled his victory. Yet it is not always the case that the value forms that auctions attach to money necessarily create such moral hierarchies.

In the European art auction that Baudrillard analyzes, bidding does not foster "rivalry between individuals ... [it] institutes a concrete community of exchange among peers" (1981:117). The difference between this auction and the one I describe derives from the commodity status of the auction prizes. The art sold at Baudrillard's auctions are unique (or near-unique) objects that cannot be valued as normal commodities. Like the standard commodity auction, the art auction lacks a stable market price that establishes a value "platform" for the prizes. (Indeed, this is the point of holding such auctions.) Thus, bidders have no way to gauge the exact quantity of (social) value that the winner has invested in the prize, relative to the loser. Fundraising auctions, because they have stable markets to serve as such a gauge, are the only type of auction whose semiotic machinery intrinsically produces hierarchy among the bidders (see, e.g., Kosansky 2002). It is noteworthy in this regard that contemporary Passerinhos claim that politicians took no special interest in the private auctions of old. As one older man said, "The politician acted just like anybody else. There was none of this sharing with the people stuff" (conversation with author, June 11, 2009). Extrapolated further, this suggests that market stability is a felicitous condition for the resolution of social uncertainty, at least in cases where the latter manifests as confusion in matters of equivalence and substitution. Thus, while anthropologists have been right to point out that social practices mediate commodity markets, the reverse is also true (Gould and von Oppen 1994:6-7; Hewitt de Alcántara 1992:7). That is, commodity markets have a special symbolic potential for expressing social relations, a potential that may derive from their diffuse power to determine people's access to resources.

\section{The Commoners' Game}

The hierarchizing machinery of the auction runs against the egalitarian ethics embodied by the commoners' bidding value: união. Unlike politicians, commoners pool equal sums of money from four to six people (usually men). Commoners usually form groups that are based on voluntary associations or work teams and sometimes on family segments. When grouped as families, they are usually comprised of kin equals (siblings, siblings-in-law, and cousins) but occasionally as spousal, parental, or avuncular units. The general gathering does not cheer for commoners when they win a bid as it often does for politicians. There is no hustle and bustle when they win a bid, because commoners extend no invitation for those around to share their winnings. The group's delegate takes the prize to the auction's dimly lit periphery and places it on the hood of one of the transport trucks that brought them to the village. Group members pick at the food at will and toast with plastic cups "that all should know that we feed ourselves by ourselves, that what feeds a man is his união with other men!" (conversation with author, June $29,2009)$. The commoners' game then seems to celebrate the egalitarian and voluntary social ties that have sprouted during Passerinho's recent democratization.

The hierarchizing effect of fundraising auction bidding affirms the winning group's união at the expense of another group. In this way, the auction format impedes the experience of pangroup communitas (i.e., a sense of shared emotional experience among the members of a group). It probably also conjures the ghost of competition among community associations within the municipal council that allocates World Bank development projects. Thus, the bidding separates and stratifies commoners in ways that recall the divisive impact that politics has on them. Moreover, the actual value of união effects a form of commensuration that undermines the purely horizontal solidarities that most bidding groups celebrate. This is because when patriarchal families and egalitarian associations bid against one another, they invest união as a value-form in the prizes, encompassing both modalities of group solidarities. Set within a fundraising auction, commoner bidding is paradoxical.

In sum, the auction offers Passerinhos an alternative to the narrative of democratic progress. Like that narrative, it creates order out of the confusion of the present political system. It tells them that old and new forms of political exchange (and group cohesion) are really "all the same thing." The political consequences that follow from this ritual message may extend beyond the municipal borders. Because 
auction victories are moral victories won through monetary supremacy, they reinforce the traditional system of municipal integration. The auction impresses commoners with the moral merit of their patrons, giving them reason to vote for their local patron's allies at higher levels of government.

\section{THE DECOMMENSURATIVE ENGAGEMENT WITH THE AUCTION FORMAT}

Passerinhos push against the messages that emerge from the typical bidding rounds. If the basic semiotic work of the fundraising auction is that of commensuration, then their agency, at the most elementary level, entails some degree of decommensuration. Despite the auction's conservative logic, this agency should not be seen as resistance but, rather, engagement. In the first place, rich politicians exercise decommensurating agency in auctions, just as commoners do. More importantly, the auction's game-like feeling makes it seductive and carnivalesque rather than dominating and oppressive (see LiPuma 2000:xii). Thus, while people may engage the auction in a critical way, they generally do so smilingly and cunningly.

The gifting of auction prizes can qualify the meanings of the bidding rounds. When Henrique gave the sweet cream to Maria, he let the public know that the two were not from rival factions - that "it was all in good fun." His gift thus subsumed Maria within his own faction. More apropos of my general point, Maria, by taking the sweet cream to the sidelines and sharing it only with her comrades from Movimento Quilombola, commented on her status as a politician. The act was a specification of her força. While the bidding expressed her generic prestige and indexed her capacity to effect multiple modalities of exchange, her sharing the prize accentuated her capacity to build lateral, egalitarian communities. It is as if this sharing was another way for her to affirm what she had originally stated when Henrique pulled her into the contest: "My força comes from my organizing the people."

In addition to the sharing and gifting of prizes, Passerinhos decommensurate their auction identities by transitioning the game between its two poles of competition: politician and commoner bidding rounds. Some high-level politicians (mayors and mayoral candidates) abstain from bidding until the middle of the event and return to the sidelines after they have won a few rounds. This abstention, they claim, reveals their democratic character. Henrique made this clear to me one day when one of his supporters described an auction at which one of his rivals zealously bid. The man telling the story noted that Henrique's rival's supporters told him to "let us bid now." Eager that I learn the lesson, Henrique turned to me and said, "Do you see that? They had to ask their boss to hold back" (conversation with author, July 1, 2009). Henrique's point was that he, as a good politician, proactively urged commoners "to feed themselves" by gracefully bowing out of the contest. I read abstention therefore as an act of inflecting a politician's generic força by highlighting his or her respect for the ideals of democracy.
This act has a counterpart in commoners' competition. Commoners shift the polarity of their bidding by matching themselves against certain other commoners who are outspoken members of the opposing political faction. Sometimes, one or more members of a commoner group will wait for someone from the other faction to bid boastfully. The commoner then springs up and counterbids as his or her patron watches from the sideline. "We need to show [our patron] that we are behind him," one man said, "that we go where he goes" (conversation with author, June 29, 2009). In this form of "matched bidding" (my term), commoners do not pay for prizes with money pooled by their group. Their patron politicians foot the bill later on and tip the man who did the bidding. In their narratives of these bidding rounds, people portray the winning group in hierarchical terms, as "the little group of so-and-so [the man who did the bidding]" (conversation with author, June 29, 2009). This rhetorical framing evokes a traditional clientelism in which patriarchs corralled the votes of their kin. Commoners therefore accentuate their potential to organize hierarchically when they want their bidding to address the electoral contestation that the general public cares about. Matched bidding, in other words, is the only way that commoners can engage in "deep play" (Geertz 1977).

Thus, both commoners and politicians displace their agency onto the opposite set of actors to maximize their ritual power (Robbins 1997:46). These acts of displacement introduce specificity into the generic value forms that bidding produces, but they are both deeply ambivalent with respect to broader questions of political change. Abstention presents a particular variety of força, the one based on egalitarian organizing, as the most virtuous. Matched bidding presents vertically arrayed commoner groups as the most salient to local politics. Taken together, these practices talk back to the auction bidding rounds. But what do they say? Abstention may reaffirm the narrative of democratic progress that the bidding rounds undermine. But because it is the prerogative of the rich (who can win), this affirmation presupposes the continued authority of the ranching class within a democratic context. Matched bidding, for its part, portrays the auction as an electoral tournament in which commoners worry about the prestige of their patron, yet it shows the crowd that patrons cannot win the day (in auctions or elections) unless united groups of commoners throw their weight behind them.

In sum, practices of gifting, abstention, and matched bidding allow Passerinhos to disaggregate the political ethics and identities that normal bidding commensurates. These engagements probably tend to salvage the narrative of democracy that normal bidding undermines, but they also suggest the continued domination of the rich within a new democratic order.

\section{CONCLUSION}

Auctions are the quintessential ritual for producing social agreement because a bidder's victory ultimately entails the 
surrender of the auction public to the bidder's valuation of the prize. They produce a pragmatic experience of public agreement without facilitating explicit, referentially oriented discussion about the world. In fundraising (and art) auctions, this surrender constitutes a collective consent to regard the winner as the source of the social value invested in the prize. ${ }^{3}$ The nature of this social value in Passerinho is to commensurate qualitatively disparate ethics, identities, and exchange modalities. Perhaps this is what Claudio Lomnitz (2001:145-164) had in mind when he noted that public ritual in rural Mexico has often existed in inverse proportion to spheres of critical debate. Passerinho's auctions preempt the formation of a public sphere not because they distract people from more argumentative genres of talk but, rather, because they undermine the critical distinctions that have emerged in everyday life. The auction simplifies social categories in ways that might change how participants think about political actors and municipal progress.

I have tried to explain this simplification process by showing how auctions commensurate the disparate political identities of the competing bidders, implicitly positing the existence of a shared abstract quality that each bidder possesses. The degree to which the bidder possesses this quality apparently governs her power to win the bidding round. Local history and political categories inform the way participants imagine this abstract power (monetary exchange, democratic organizing, family solidarity, etc.), but the latter is not reducible to preexisting social categories. Rather, the ritual draws on money's capacity to signify a person's hidden potential for unlimited action, such that the bids produce more generic categories of value (força or união) than those that circulate in everyday life.

The power of bidding money to commensurate the participants' identities does not entail a hiatus of exchange value. I have argued that the money bid implicitly signifies both the prize's commodity value and the personal value of the bidders (força and união): bidders have the sensation that their personal value is calculable precisely because they know the approximate commodity value of the auction prizes on which they are "overbidding." I have posited, in fact, that the fundraising variety of auction is especially apt for this semiotic process because participants typically know the exact commodity value of the prizes. The commodity value acts as a zero-point against which the amount of added força or união can be calculated through an implicit subtraction (amount bid - commodity value $=$ personal value). The personal value indexed by the bids thus exists in relative terms. It is relative both to the prize's exchange value (a qualitative difference) and to the rival bidder's personal value (a quantitative difference).

The perception of quantifiable differences in personal value enables the bidding at fundraising auctions to produce ritual hierarchies. Crucially, these hierarchies may also influence the way Passerinhos come to view the field of political candidates in the municipal elections. Passerinho's auctions offer its participants a series of clarifications that help them deal with the confusing simultaneity of multiple political ethics. Their commensurating function sends a message to the bidders that these three modes of gaining prestige are, at heart, the same thing and that a given politician is capable of all of them. The hierarchizing function relegitimates the authority of the same class of actors that have held power in Passerinho for many years. Both functions displace the teleology of democratic progress that could otherwise sort out the relationship among these ethics by creating a municipal project of phasing out clientelism. In this way, the fundraising auction builds on public agreement regarding the exchange value of objects to create public agreement regarding the value of persons.

I have sought to temper my description of the auction's commensurating aspect by documenting the decommensurating agency through which actors reaffirm key differences among political ethics and identities. I have shown how participants can accentuate their democratic character through gifts and other practices, although I have been forced to admit that this agency serves conservative interests as well. Still, the auction must be acknowledged as an important new medium - albeit a flawed one - through which all Passerinhos express some kind of relationship to insurgent politics. I cannot posit this without recalling something Maria once told me. She said she hated auctions because "all Passerinho politics have become like an auction... and how can a person like me win that way?" (conversation with author, July 1, 2009). I see her point, but I think it is also important to view the auction not as anathema to democracy but, rather, as a site at which people use money to mediate democracy.

\begin{abstract}
Aaron Ansell Department of History and Anthropology, Monmouth University, West Long Branch, NJ 07764-1898, aansell@monmouth.edu
\end{abstract}

\section{NOTES}

Acknowledgments. I extend my sincerest thanks to my anonymous reviewers and to Editor-in-Chief Tom Boellstorff for their generous, tireless, and insightful readings of various drafts of this article. Steven Kosiba, William Mitchell, and Lisa Vetere, my colleagues at Monmouth University, read early drafts and gave me useful feedback on the issues of value and clientelism. Michael Silverstein's patient correspondence helped me to frame succinctly the general thrust of my argument. My dear friend Rebecca Goodberg made my prose more tolerable. Michael Richison, from the Department of Art and Design at Monmouth University, helped me to capture and enhance still images of an auction, making it possible for me to study and present them. Finally, I continue to reap the rewards of research funding from the Wenner Gren and Fulbright Hays Foundations.

1. While I persistently claimed my neutrality with regard to the municipal election of 2004, this claim became increasingly difficult to perform convincingly. My initial contacts 
had been people identified with the opposition faction, and as the electoral bifurcation of the municipality intensified, my acquaintances allied with the incumbent faction refused to speak to me. I exacerbated the situation by silently attending the opposition's closed-door strategy session under the condition that no one would claim to have my political support. It was a blurry line to walk, and I feel now that I compromised the ethics of informed consent by representing myself as politically neutral while engaging in behavior that, at least from the outside, was totally inconsistent with neutrality. My "expulsion" followed an incident in which Henrique, then the opposition candidate, publically extended his hand for me to shake while I stood in the audience of a mass political rally. (He wanted to show off his cache of outside endorsement.) There in the middle of the crowd, I took his hand, not knowing what else to do. The following day, the mayor's lawyer and the regional constable called me into the police station and told me that they could not protect me against those who might wish to do me harm. That afternoon, I learned that the mayor's son-in-law, who had beaten up a union leader from the opposition, intended to club me into hospitalization. Frightened, I left for the state capital that evening. A few weeks later, the elections passed, Henrique won, and my friends called me to tell me that it was safe to return because things had cooled off and that people from opposing factions were becoming friends again. Indeed, I rebuilt my connections with the former mayor's allies and have continued my fieldwork without any further incident of this nature.

2. I am uncertain as to how widespread are the fundraising auctions I analyze here. While individuals in Passerinho claim credit for their "invention," a priest from a municipality 50 kilometers away claimed to have participated in similar auctions throughout the southeastern area of Piaui. A consultant I interviewed at a major bus station said her village association in Bahia held one as well.

3. I believe a curvilinear relationship exists between the public's knowledge of the auction prizes' exchange values and the degree to which the identities of the bidders act as value forms to determine the sale price of the prizes. In other words, if the exchange value is either totally unknowable (as in art auctions) or absolutely knowable (as in fundraising auctions), then the bidders' identities will create the price. Otherwise, auction prices will reflect speculative capital investment and other forms of economic reasoning.

\section{REFERENCES CITED}

Adriance, Madeleine

1994 Base Communities and Rural Mobilization Northern Brazil. Sociology of Religion 55(2):163-178.

Amman, Edmund, and Werner Baer

2000 The Illusion of Stability: The Brazilian Economy under Cardoso. World Development 28:1805-1819.

Appadurai, Arjun

1986 Introduction: Commodities and the Politics of Value. In The Social Life of Things: Commodities in Cultural Perspec- tive. Arjun Appadurai, ed. Pp. 3-64. Cambridge: Cambridge University Press.

Barber, Karin

1995 Money, Self-Realization, and the Person in Yorúba Texts in Money Matters: Instability, Values, and Social Payments in the Modern History of West African Communities. In Money Matters: Instability, Values and Social Payments in the Modern History of West African Communities. Jane Guyer, ed. Pp. 205-225. Portsmouth: Heinemann.

Barreira, César

2006 Fraudes e Currupções Eleitorais: Entre dádivas e contravenções [Electoral fraud and corruption: Between gifts and misdemeanors]. In Política no Brasil: Visões de Antropólogos [Politics in Brazil: Visions of anthropologists]. M. Palmeira and C. Barreira, eds. Pp. 151-165. Rio de Janeiro: Relume Dumará.

Baudrillard, Jean

1981 For a Critique of the Political Economy of the Sign. St. Louis, MO: Telos.

Bohannan, Paul J., and Laura Bohannan

1968 Tiv Economy. Evanston, IL: Northwestern University Press.

Cassady, Ralph

1967 Auctions and Auctioneering. Berkeley: University of California Press.

Cattelino, Jessico R.

2009 Fungibility: Florida Seminole Casino Dividends and the Fiscal Politics of Indigeneity. American Anthropologist 111(2):190-200.

Chaves, Christine de Alencar

2003 Festas da Política: Uma etnografia da modernidade no sertão (Buritis-MG) [Political festivals: An ethnography of modernity in the backlands]. Rio de Janeiro: Relume Dumará.

Collins, John

2008 Public Health, Patronage and National Culture: The Resuscitation and Commodification of Community Origins in Neoliberal Brazil. Critique of Anthropology 28(2):237255.

Comaroff, Jean, and John Comaroff

1999 Occult Economies and the Violence of Abstract: Notes from the South Africa Postcolony. America Ethnologist 26(2):279302.

Costa, Alberto, Conrad P. Kottack, and Rosane Prado

1997 The Sociopolitical Context of Participatory Development in Northeast Brazil. Human Organization 56(2):138-146.

Craig, David, and Doug Porter

2006 Development beyond Neoliberalism? New York: Routledge.

Dent, Alexander Sabastian

2007 Country Brothers: Kinship and Chronotope in Brazilian Rural Public Culture. Anthropological Quarterly 80(2):455495.

Farina, Elizabeth

2002 Consolidation, Multinationalisation, and Competition in Brazil: Impacts on Horticulture and Dairy Products Systems. Development Policy Review 20(4):441-457. 
French, Jan

2006 Buried Alive: Imagining Africa in the Brazilian Northeast. American Ethnologist 33(3):340-360.

Garsten, Christina, and Anna Hasselström

2003 Risky Business: Discourses of Risk and (Ir)Responsibility in

Globalizing Markets. Ethnos 68(2):249-270.

Geertz, Clifford

1977 Notes on a Balinese Cockfight. In The Interpretation of Cultures. Pp. 412-455. New York: Basic.

Geschiere, Peter

1997 The Modernity of Witchcraft: Politics and the Occult in Postcolonial Africa. Charlottesville: University of Virginia Press.

Goodwin, Charles

2002 Time in Action. Special issue, "Repertoires of Timekeeping in Anthropology," Current Anthropology 43(supp. AugustOctober):19-35.

Gould, Jeremy, and Achim von Oppen

1994 Of Rhetoric and Market: The "Liberalization" of Food Trade in East Africa. Sociologia Ruralis 34(1):3-12.

Graeber, David

2001 Toward an Anthropological Theory of Value. New York: Palgrave Macmillan.

Green, James

2000 Introduction. Special issue, "Brazil in the Aftershock of Neoliberalism,” Latin American Perspectives 27(6):5-8.

Green, Stephen

2000 Negotiation with the Future: The Culture of Modern Risk in Global Financial Markets. Society and Space 18(1): 77-89.

Guyer, Jane

2004 Marginal Gains: Monetary Transactions in Atlantic Africa. Chicago: University of Chicago Press.

Hall, Anthony

2006 From Fome Zero to Bolsa Família: Social Policies and Poverty Alleviation under Lula. Journal of Latin American Studies 38(4):689-709.

Helfand, Steven

2003 The Impact of Agricultural Policy Reforms on the Agricultural Sector in Brazil in the 1990s: Implications for ProPoor Agricultural Policies. Paper presented at Organization for Economic Co-Operation and Development Global Forum on Agriculture: Designing and Implementing Pro-Poor Agricultural Policies, Paris, December 10-13.

Heredia, Beatriz M. A.

1996 Comunidade, Família, Política [Community, family, and politics]. In Antropologia, Voto E Representação Política [Anthropology, the vote and political representation]. M. Palmeira and M. Goldman, eds. Pp. 52-72. Rio de Janeiro: Contracapa.

Hewitt de Alcántara, Cynthia

1992 Markets in People and Practice. European Journal of Development Research 4:1-16.

Holston, James

2008 Insurgent Citizenship: Disjunctions of Democracy and Modernity in Brazil. Princeton: Princeton University Press.
Holt, Charles A., Jr.

1980 Competitive Bidding for Contracts under Alternative Auction Procedures. Journal of Political Economy 88(3):433445.

Kelly, John D.

1992 Fiji Indians and "Commoditization of Labor." American Ethnologist 19(1):97-120.

Kosansky, Oren

2002 Tourism, Charity, and Profit: The Movement of Money in Moroccan Jewish Pilgrimage. Cultural Anthropology 17(3):359-400.

Leal, Victor Nunes

1977[1949] Coronelismo: The Municipality and Representative Government in Brazil. Cambridge: Cambridge University Press.

LiPuma, Edward

2000 Encompassing Others: The Magic of Modernity in Melanesia. Ann Arbor: University of Michigan Press.

Lomnitz, Claudio

2001 Deep Mexico, Silent Mexico: An Anthropology of Nationalism. Minneapolis: University of Minnesota Press.

Maurer, Bill

2006 The Anthropology of Money. Annual Review of Anthropology 35:15-36.

Mott, Luiz

1985 Piaui Colonial: População, Economia e Sociedade [Colonial Piaui: Population, economy and society]. Teresina: Projeto Petrônio Portella.

Munn, Nancy D.

1992 The Fame of the Gawa: A Symbolic Study of Value Transformation in a Massim (Papua New Guinea) Society. Cambridge: Cambridge University Press.

Myerson, R. B.

1981 Optimal Auction Design. Mathematics of Operations Research 6:58-73.

O'Dougherty, Maureen

1999 The Devalued State and Nation: Neoliberalism and the Moral Economy Discouse of the Brazilian Middle Class, 1986-1994. Latin American Perspectives 26(1):151-174.

Palmeira, Moacir

1996 Política, Facções e Voto [Politics, factions, and the vote]. In Antropologia, Voto e Representação Política [The anthropology, the vote and political representation]. M. Palmeira and M. Goldman, eds. Pp. 41-56. Rio de Janeiro: Contra Capa.

Parry, Jonathan, and Maurice Bloch

1989 Money and the Morality of Exchange. Cambridge: Cambridge University Press.

Pastor, Manuel, and Carlo Wise

1999 The Politics of Second-Generation Reform. Journal of Democracy 10(3):34-48.

Riley, John G., and William F. Samuelson

1981 Optimal Auctions. American Economic Review 71(3):381392.

Robbins, Joel

1997 Equality as a Value: Ideology in Dumont, Melanesia, and the West. Social Analysis 36(October):21-70. 
Simmel, Georg

1964 The Sociology of Georg Simmel. Kurt H. Wolff, ed. New York: Free Press.

Smith, Charles

1990 Auctions: The Social Construction of Value. Berkeley: University of California Press.

Soares, Fábio, Sergei Soares, Marcelo Medeiros, and Rafael Osório 2006 Programas de Transferência de Renda no Brasil: Impactos Sobre a Desigualdade [Income transfer programs in Brazil: Impacts on social inequality]. Anais do XXXIV Encontro Nacional de Economia [Proceedings of the 34th Brazilian economics meeting] 156. Pp. 1-43. Salvador, Bahia: ANPEC - Associação Nacional dos Centros de Pósgraduação em Economia [Brazilian Association of Graduate Programs in Economics].

Veras, Renato, ed.

2001 Velhice numa Perspectiva de Futuro Saudável [Old age from the perspective of future health]. Rio de Janeiro: Universidade Estadual do Rio de Janeiro.

Villela, Jorge Mattar

2004 O Dinheiro e Suas Diversas Faces nas Eleições Municipais em Pernambuco [Money and its diverse faces in the municipal elections of Pernambuco]. Mana 11(1):267296.

Whitehead, Harriet

2002 Eager Subjects, Reluctant Powers: The Irrelevance of Ideology in a Secret New Guinea Male Cult. In Power and the Self. Jeannette Maria Mageo, ed. Pp. 177-194. Cambridge: Cambridge University Press.

Woodard, James P.

2005 Coronelismo in Theory and Practice: Evidence, Analysis, and Argument from São Paulo. Luso-Brazilian Review 42(1):99-117.

Zheng, Charles Zhoucheng

2002 Optimal Auction with Resale. Econometrica 70(6):21972224.

\section{FOR FURTHER READING}

(These selections were made by the American Anthropologist editorial interns as examples of research related in some way to this article. They do not necessarily reflect the views of the author.)

Benson, Peter

2008 Good Clean Tobacco: Philip Morris, Biocapitalism, and the Social Course of Stigma in North Carolina. American Ethnologist 35(3):357-379.

Cardarello, Andrea

2009 The Movement of the Mothers of the Courthouse Square: "Legal Child Trafficking," Adoption and Poverty in Brazil. Journal of Latin American and Caribbean Anthropology 14(1):140 161.

French, Jan Hoffman

2004 Mestizaje and Law Making in Indigenous Identity Formation in Northeastern Brazil: "After the Conflict Came the History." American Anthropologist 106(4):663-674.

Gordillo, Gastón

2002 The Dialectic of Estrangement: Memory and the Production of Places of Wealth and Poverty in the Argentinean Chaco. Cultural Anthropology 17(1):3-31.

Penglase, Ben

2009 States of Insecurity: Everyday Emergencies, Public Secrets, and Drug Trafficker Power in a Brazilian Favela. PoLAR: Political and Legal Anthropology Review 32(1):47-63.

Sivaramakrishnan, K.

2000 Crafting the Public Sphere in the Forests of West Bengal: Democracy, Development, and Political Action. American Ethnologist 27(2):431-461.

Strassler, Karen

2009 The Face of Money: Currency, Crisis, and Remediation in Post-Suharto Indonesia. Cultural Anthropology 24(1):68103.

Weiner, Annette B.

1985 Inalienable Wealth. American Ethnologist 12(2):210-227. 